\title{
Carcass and meat characteristics from dairy-origin steers fed with diets based on ground pearl millet grain, containing inclusion levels of babassu mesocarp meal
}

\section{Características de carcaça e carne de novilhos de origem leiteira alimentados com dietas à base de grão de milheto, contendo níveis de inclusão de farelo do mesocarpo do babaçu}

\author{
Wanderson Martins Alencar ${ }^{1}$; João Restle ${ }^{2}$; Regis Luis Missio ${ }^{3}$; \\ José Neuman Miranda Neiva**; Fabrícia Rocha Chaves Miotto"; \\ Aline Evangelista Machado Santana ${ }^{5}$; Wescley Faccini Augusto ${ }^{5}$; \\ Ithálo Barros de Freitas ${ }^{6}$; Denise Adelaide Gomes Elejalde ${ }^{7}$
}

\begin{abstract}
This study aimed to evaluate carcass and meat characteristics of feedlot-finished steers of dairy origin fed with pearl millet grain-based diets, containing inclusion levels of babassu mesocarp bran (BMB) $(0,12,24,36$ and $48 \%)$. A total of 30 Holstein-Zebu crossbred steers with an average initial weight of $371.02 \pm 27 \mathrm{~kg}$ were randomly divided into six groups fed with different experimental diets (five pearl millet-based diets containing inclusion levels of BMB and one standard corn-based diet). Each diet had five replications. Isonitrogenous diets had a roughage/concentrate ratio of 20/80. BMB inclusion level in the diet reduced slaughter and carcass weight from 488.4 and $242.2 \mathrm{~kg}$ to 454.0 and $226.7 \mathrm{~kg}$, respectively. The subcutaneous fat thickness, conformation, and pistol cut weight were also reduced to $38.8,13.6$, and $9 \%$, respectively, as the BMB inclusion level in the diet increased. Meat characteristics were not affected by BMB inclusion levels in the diet. Regarding carcass and meat characteristics, no difference was observed in the analysis of contrasts between BMB diets and corn- or millet-based diets, or between corn- or millet-based diets. The inclusion of BMB in millet-based diets should consider the cost/benefit ratio, as it reduces slaughter and carcass weight, while the main meat characteristics remain unchanged. However, total substitution of corn by millet grains in feedlot diets does not alter caracteristics of carcass and meat of dairy steers.
\end{abstract}

Key words: By-products, carcass, corn, marbling, meat, primary cuts, subcutaneous fat

\footnotetext{
${ }^{1}$ Discente do Curso de Mestrado do Programa de Pós-Graduação em Ciência Animal Tropical, Universidade Federal do Tocantins, UFT, Araguaína, TO, Brasil. E-mail: wanderson alencar@hotmail.com

2 Bolsista PVNS-Capes, UTF, Araguaína, TO, Brasil. E-mail: jorestle@terra.com.br

${ }^{3}$ Prof., Universidade Tecnológica Federal do Paraná, UTFPR, Pato Branco, PR, Brasil. E-mail: regisluismissio@gmail.com

${ }^{4}$ Profs., UFT, Araguaína, TO, Brasil. E-mail: araguaia2007@gmail.com; fabriciarchaves@hotmail.com

${ }^{5}$ Discentes do Curso de Doutorado do Programa de Pós-Graduação em Ciência Animal Tropical, UFT, Araguaína, TO, Brasil. E-mail: aline1machado@uft.edu.br; wescleyfaccini@hotmail.com

${ }^{6}$ Discente do Curso de Graduação em Zootecnia, UFT, Araguaína, TO, Brasil. E-mail: ithalobf@gmail.com

${ }^{7}$ Bolsista de Pós-Doutorado do Programa de Pós-Graduação em Ciência Animal Tropical, UFT, Araguaína, TO, Brasil. E-mail: denise.elejalde@gmail.com

* Author for correspondence
} 


\section{Resumo}

Objetivou-se avaliar as características da carcaça e carne de novilhos mestiços de origem leiteira terminados em confinamento com dietas a base de grãos de milheto, contendo níveis de inclusão de farelo do mesocarpo do babaçu $(0,12,24,36$ e $48 \%)$. Foram utilizados 30 novilhos mestiços HolandêsZebu com peso inicial médio de $371,02 \pm 27 \mathrm{~kg}$ distribuídos aleatoriamente em seis dietas experimentais (cinco dietas a base de milho contendo níveis de inclusão de farelo do mesocarpo do babaçu e uma dieta padrão a base de milho), cada uma com cinco repetições. As dietas isonitrogenadas apresentam relação volumoso/concentrado de 20/80. O aumento do nível de inclusão do FMB na dieta reduziu o peso de abate e de carcaça de 488,4 e 242,2 kg para 454,0 e 226,7 kg, respectivamente. A espessura de gordura subcutânea, conformação e peso do traseiro especial reduziram, respectivamente, 38,8; 13,6 e 9\% pelo aumento do nível de farelo do mesocarpo de babaçu na dieta. As características da carne não foram alteradas pelos níveis de inclusão de farelo do mesocarpo de babaçu na dieta. Não foi verificada diferença, pela análise de contrastes, entre as dietas com farelo do mesocarpo do babaçu e as dietas com milho ou milheto, ou entre as dietas a base de milho ou milheto para as características de carcaça e carne avaliadas. A inclusão de farelo do mesocarpo do babaçu em dietas a base de grão de milheto deve considerar a relação custo/benefício, pois promove queda do peso de abate e de carcaça apesar de não alterar as principais características da carne. A substituição total do grão de milho pelo grão de milheto em dietas de confinamento, por outro lado, não altera as principais características de carcaça e carne de bovinos de origem leiteira.

Palavras-chave: Carcaça, carne, cortes primários, gordura subcutânea, marmoreio, milho, subprodutos

\section{Introduction}

Production of dairy steers in Brazil is far short of its potential. This situation reflects the high discharge of males after birth in dairy farms. In non-discarded males, food, in general, is poor, causing high mortality during growth phases or delaying the development of the surviving animals; thereby compromising important features such as carcass yield, muscle development and meat quality. The production of feedlot dairy steers, in this context, is an alternative to increase meat production and farmer income without reducing grazing areas for milk production. In addition, the use of confinement reduces the slaughter age (MENEZES et al., 2010) and might result in better carcass quality and higher meat production (KUSS et al, 2010; MISSIO et al, 2010). Further, the high-energy diet supplied in confinement per se increases the deposition of body fat, thereby increasing the carcass subcutaneous fat thickness and meat marbling (PETHICK et al., 2004). This may or may not complement slaughter age reduction that can lead to carcass and meat quality improvements (LI et al., 2006; VAZ et al., 2012). The use of confinement for beef production, however, is expensive, mainly due to the high costs of concentrate feed (RESTLE et al., 2007).

The use of lower cost feed than those traditionally used can be an alternative to reduce the cost in confinement. Pearl millet, with a market value of $\leq 77.78 \%$ of the cost of corn, can be used instead of corn in feedlot diets, without causing any change in animal performance (SILVA et al., 2014). The use of pearl millet (Pennisetum americanum) has increased in mid-western and northern regions of Brazil, accompanied by the increase in areas used for soybean (Glycine max) cultivation, generating increased grain production, which may be used for animal feed. Millet is one of the main crops used in rotation with soybean and can be used for grazing and production of straw in a no-tillage system for grain production as a replacement for corn (of highest off-season risk) and/or for silage (BERGAMASCHINE et al., 2011). 
Babassu (Orbynia speciosa) is a native palm tree found in the mid-western, northern and northeastern regions of Brazil, Colombia, and Central America. Brazilian babassu cultivation comprises approximately 9.57 million hectares, with a production potential of 10.7 billion tons of fruit per year, in its natural form. The exploitation of babassu has great socio-economic importance in the northern and north-eastern regions of Brazil, involving over 450,000 peasant families who collect and process the babassu fruits (TEIXEIRA; CARVALHO, 2007; TEIXEIRA, 2008). The babassu fruit is used in various forms such as flour and oil for human consumption, animal feed, and charcoal, among others. Babassu mesocarp bran (BMB) is produced from the mesocarp (23\% of the fruit), which has large regional supply, is of low cost, and has potential application as an animal feed (SILVA et al., 2012; CRUZ et al., 2014). Nevertheless, there are few studies on the effects of this byproduct on carcass characteristics and meat.

Considering the above, the present study aimed to evaluate the effect of pearl millet-based diets, containing BMB inclusion levels, on carcass and meat characteristics of feedlot-finished dairy steers.

\section{Materials and Methods}

The study was conducted at the School of Veterinary Medicine and Animal Science of the Federal University of Tocantins, Araguaína Campus, located $07^{\circ} 11^{\prime} 28^{\prime \prime} \mathrm{S}$ and $48^{\circ} 12^{\prime} 26^{\prime \prime}$ W. A total of 30 dairy steers of 27 months of age, with an average initial weight of $371.02 \pm 27 \mathrm{~kg}$ were used. The animals were kept in individual pens $\left(12 \mathrm{~m}^{2}\right)$ with concrete floors, and provided with food and water. The confinement period was 98 days and the period of adaptation to facilities, diets, and handling management was 14 days. At the start of the acclimatization period, the animals were wormed and supplemented with vitamins A, D and E.

The treatments consisted of millet-based diets containing BMB in increasing proportions $(0,12$, 24, 36 and 48\%) replacing millet, and a standard corn-based diet, keeping the roughage/concentrate ratio at 20/80 (Table 1). The diets were formulated to be isonitrogenous, considering a dry matter intake of $2.4 \%$ of body weight (BW) according to NRC (1996). Feed intake was recorded daily, with about $10 \%$ leftover, and the feed was supplied once a day (10 a.m.). The food intake during the experimental period was $2.2,2.5,2.8,3.4$, and $2.7 \%$ of $\mathrm{BW}$ for diets with $0,12,24,36$, and $48 \% \mathrm{BMB}$, and $2.3 \%$ of BW for the corn-based diet. The resulting average daily weight gain was $1.44,1.37,1.33,1.29$, and $0.91 \mathrm{~kg} \mathrm{day}^{-1}$ for diets containing $0,12,24,36$, and $48 \% \mathrm{BMB}$, respectively, and $1.32 \mathrm{~kg} \mathrm{day}^{-1}$ for the corn-based diet.

To determine the food chemical composition (Table 2), samples were collected weekly, which were packaged, identified, and frozen at $-20^{\circ} \mathrm{C}$. At the end of the feeding period, the samples were thawed, pre-dried in an oven with forced air ventilation at $55^{\circ} \mathrm{C}$ for $72 \mathrm{~h}$ and processed in a Wiley mill with a $1 \mathrm{~mm}$ mesh sieve. The dry matter $(\mathrm{DM})$, mineral matter (MM), ether extract (EE), and crude protein $(\mathrm{CP})$ contents were determined according to AOAC (1995). The neutral detergent fiber (NDF) was determined according to Van Soest et al. (1991). The non-fiber carbohydrate content (NFC) was determined according Sniffen et al. (1992), where: $\mathrm{TC}=100-(\mathrm{CP}+\mathrm{EE}+\mathrm{MM}$ $+\mathrm{NDF})$. 
Table 1. Composition of the diets ( $\%$ of dry matter).

\begin{tabular}{lcccccc}
\hline \multirow{2}{*}{ Items } & \multicolumn{4}{c}{ \% BMB in the diet } & Ground \\
\cline { 2 - 5 } & 0 & 12 & 24 & 36 & 48 & corn \\
\hline Elephant grass silage & 20.00 & 20.00 & 20.00 & 20.00 & 20.00 & 20.00 \\
Ground corn & -- & -- & -- & -- & -- & 70.84 \\
Ground pear millet grain & 77.79 & 65.01 & 52.37 & 36.45 & 20.62 & -- \\
Babassu mesocarp bran (BMB) & -- & 12.39 & 24.68 & 36.83 & 48.86 & -- \\
Soybean meal & -- & -- & -- & 3.76 & 7.57 & 6.95 \\
Limestone & 0.58 & 0.97 & 1.33 & 1.33 & 1.33 & 0.58 \\
Urea & 0.79 & 0.80 & 0.79 & 0.80 & 0.79 & 0.79 \\
Mineral mixture & 0.54 & 0.53 & 0.53 & 0.53 & 0.53 & 0.54 \\
Sodium chloride & 0.26 & 0.26 & 0.26 & 0.26 & 0.26 & 0.26 \\
Rumensin ${ }^{@}$ & 0.03 & 0.03 & 0.03 & 0.03 & 0.03 & 0.03 \\
Ammonium sulfate & 0.01 & 0.01 & 0.01 & 0.01 & 0.01 & 0.01 \\
DM, \% & 72.91 & 73.01 & 73.08 & 73.43 & 73.29 & 73.33 \\
Crude protein & 13.19 & 12.50 & 12.97 & 13.38 & 13.27 & 11.99 \\
Neutral detergent fiber & 23.41 & 26.79 & 31.13 & 34.08 & 41.45 & 23.77 \\
Metabolizable energy, Mcal kg ${ }^{-1}$ of DM & 3.07 & 2.94 & 2.78 & 2.72 & 2.63 & 3.09 \\
\hline
\end{tabular}

$\mathrm{DM}=$ dry matter.

Table 2. Chemical composition of ingredients ( $\%$ of dry matter).

\begin{tabular}{lccccc}
\hline \multirow{2}{*}{ Nutrients } & \multicolumn{5}{c}{ Ingredients } \\
\cline { 2 - 5 } & Elephant grass & GC & Millet & BMB & Soybean bran \\
\hline DM, \% of natural matter & 24.21 & 84.44 & 86.57 & 83.83 & 90.88 \\
Ash & 1.35 & 1.28 & 1.76 & 5.04 & 6.50 \\
Crude protein & 3.96 & 7.73 & 12.98 & 3.05 & 48.09 \\
Ether extract & 2.15 & 3.78 & 3.49 & 1.25 & 1.50 \\
Neutral detergent fiber & 70.00 & 11.66 & 10.91 & 36.03 & 19.15 \\
Non-fibrous carbohydrates & 10.42 & 75.56 & 70.86 & 54.64 & 24.76 \\
\hline
\end{tabular}

$\mathrm{GC}=$ ground corn, $\mathrm{BMB}=$ babassu mesocarp bran.

The animals were slaughtered at a commercial slaughterhouse with supervision of the Federal Inspection Service. Prior to the slaughter, the animals were subjected to solid and liquid fasting for 14-16 h. After slaughter, carcasses were identified, divided in half and cooled for 24 hours at temperatures ranging from 0 to $2^{\circ} \mathrm{C}$. After cooling, the carcasses were weighed and evaluated subjectively on conformation (1-3: inferior; 4-6: bad: 7-9: regular; 10-12: good; 13-15: very good; 16-18: superior) and physiological maturity (1-3: over 8 years of age; 4-6: 5.5 to 8 years of age; 7-9: 4 to 5.5 years old; 10-12: 2.5 to 4 years old; 13-15: less than 2.5 years of age) according to the methods described by Müller (1987). The cold carcass yield was obtained by the ratio of cold carcass and slaughter weight.

In the right half of the carcass, metric measurements were taken: carcass length (from the front edge of the pubic bone to the medial anterior edge of the first rib), cushion thickness (between the medial and lateral face of the upper thigh), leg length (from the tibial-tarsal joint to the front edge of 
the pubis) and arm (from the radiocarpal joint until the end of the olecranon) and arm circumference (middle of the radioulnar segment and muscles that cover this region). After, from this same halfcarcass, the HH section was removed, according to the methodology of Hankins and Howe (1946). On the surface of the cranial portion of the $\mathrm{HH}$ section, the area of the longissimus dorsi muscle was determined, from its outline on vellum. In this same region, the degree of marbling was subjectively determined $(1$ to $3=$ trace; 4 to $6=$ slight; 7 to $9=$ small; 10 to $12=$ medium; 13 to $15=$ moderate; 16 to $18=$ abundant), as well as muscle fiber texture $(1=$ very coarse; $2=$ coarse; $3=$ slightly coarse; $4=$ thin; $5=$ very thin $)$ and the meat color $(1=$ dark; 2 $=$ dark red; $3=$ slightly dark red; $4=$ red; $5=$ bright red). The evaluations were performed after 30 minutes of exposure to air (MÜLLER, 1987). After that, the $\mathrm{HH}$ section was dissected into muscle, fat and bone and weighed to estimate their proportions in the carcass according to the methodology of Hankins and Howe (1946).

The left half of the carcass was separated into primary cuts, where the forequarter were separated from pistol cut and short ribs between the $5^{\text {th }}$ and $6^{\text {th }}$ rib bone, including neck, shoulder, arm, and five ribs. Through the rib cut at $22 \mathrm{~cm}$ of the vertebral column, it was possible to separate the pistol cut from the short ribs, which included the ribs from the sixth bones on, plus the abdominal muscles. After separation, the cuts were weighed, and their relative weight to the half-carcass was determined.

Data was subjected to analysis of variance and orthogonal contrasts, being the sum of squares of the treatments separated into three contrasts: diets with BMB vs. corn-based diet $\left(\begin{array}{llllll}0 & 1 & 1 & 1 & 1 & -4\end{array}\right)$, millet-based diet $v s$. corn-based diet $\left(\begin{array}{llllll}1 & 0 & 0 & 0 & 0 & -1\end{array}\right)$ or diets with BMB (4 -1 -1 -1 -1 0$)$. The effect of BMB inclusion level was evaluated separately by regression analysis, considering $\alpha=5$. The general mathematical model used was represented by: $\gamma_{\mathrm{ij}}=\mu$ $+\tau_{\mathrm{i}}+\varepsilon_{\mathrm{ij}}$, where: $\gamma_{\mathrm{ij}}=$ dependent variable; $\mu=$ overall mean; $\tau_{\mathrm{i}}=$ diet effect; $\varepsilon_{\mathrm{ij}}=$ residual experimental error. In the regression analysis, the mathematical model was represented by: $\gamma_{i j}=\beta_{0}+\beta_{1} X_{i}+\beta_{2} X_{i}^{2}+$ $\beta_{3} X_{i}^{3}+\alpha_{j+} \varepsilon_{i j}$, where: $\gamma_{i j}=$ dependent variable; $\beta$ 's $=$ regression coefficients; $X_{i}=$ independent variables; $\alpha_{\mathrm{j}}=$ regression deviations; and $\varepsilon_{\mathrm{ij}}=$ residual random error.

\section{Results and Discussion}

Regression analysis showed a significant $(\mathrm{P}<$ 0.05) negative linear relationship between $\mathrm{BMB}$ level and cold carcass weight (Table 3 ). Despite this reduction, significant differences were not found by analysis of contrasts on the cold carcass weight between BMB diets and corn- or milletbased diets. There was also no difference for the cold carcass weight between corn- and milletbased diets. The reduction in carcass weight with increasing inclusion of $\mathrm{BMB}$ in the diet can be explained by reduced body weight at slaughter. The results were consistent with those observed by Miotto et al. (2012a), who found a reduction in carcass weight with increasing substitution levels of BMB for corn $(0,25,50,75$, and $100 \%)$ in bulls' diet. Cruz et al. (2015a) found no change in carcass weight when including $35 \%$ of $\mathrm{BMB}$ in diets containing different corn concentration levels (65 and $71 \%$ ), demonstrating the feasibility of using small proportions of BMB in cattle diet. From the results obtained and presented in the literature (MIOTTO et al., 2012a; CRUZ et al., 2015a), it is assumed that in addition to the BMB level in the diet, food nutritional characteristics (notably the energy content) replaced by BMB in the diet are keys factors affecting body development and consequently carcass weight of feedlot cattle. Further, the results obtained between corn- or millet-based diets for the cold carcass weight are consistent with those obtained by Silva et al. (2015), who found no change in cattle carcass weight fed with varying millet levels $(0,33,66$, and $100 \%)$ replacing corn. 
Table 3. Carcass characteristics of steers fed diets based on pearl millet containing inclusion levels of babassu mesocarp bran (BMB), and diet based on corn grain.

\begin{tabular}{|c|c|c|c|c|c|c|c|c|c|c|}
\hline \multirow{2}{*}{ Items } & \multicolumn{5}{|c|}{$\%$ of BMB in the diet } & \multirow{2}{*}{$\begin{array}{l}\text { Corn } \\
\text { control }\end{array}$} & \multirow{2}{*}{$\begin{array}{l}\mathrm{CV} \\
(\%)\end{array}$} & \multicolumn{3}{|c|}{ Orthogonal contrasts } \\
\hline & 0 & 12 & 24 & 36 & 48 & & & A & $\mathrm{B}$ & $\mathrm{C}$ \\
\hline $\mathrm{SW}, \mathrm{kg}$ & 488.4 & 483.1 & 481.6 & 482.4 & 454.0 & 478.50 & 7.27 & 0.65 & 0.87 & 0.46 \\
\hline $\mathrm{CCW}, \mathrm{kg}$ & 242.24 & 247.48 & 230.84 & 239.84 & 226.72 & 239.04 & 7.27 & 0.65 & 0.87 & 0.46 \\
\hline $\mathrm{CCY}, \%{ }^{*}$ & 49.60 & 51.23 & 47.93 & 49.72 & 49.94 & 49.96 & 4.17 & 0.81 & 0.72 & 0.63 \\
\hline SFT, mm & 5.55 & 5.35 & 3.55 & 3.65 & 4.00 & 3.55 & 20.91 & 0.08 & 0.51 & 0.12 \\
\hline SFT, \%* & 2.29 & 2.16 & 1.54 & 1.52 & 1.76 & 1.49 & 20.91 & 0.08 & 0.45 & 0.12 \\
\hline PM, points & 10.80 & 10.40 & 11.00 & 10.80 & 10.40 & 11.20 & 7.29 & 0.43 & 0.17 & 0.71 \\
\hline $\mathrm{CC}$, points & 10.00 & 9.80 & 9.60 & 10.20 & 8.80 & 9.40 & 11.76 & 0.41 & 0.73 & 0.49 \\
\hline LDA, $\mathrm{cm}^{2}$ & 53.02 & 56.61 & 52.48 & 55.82 & 53.71 & 55.50 & 8.75 & 0.42 & 0.73 & 0.50 \\
\hline LDA, $\%^{*}$ & 21.89 & 22.87 & 22.73 & 23.27 & 23.69 & 23.22 & 7.61 & 0.32 & 0.96 & 0.20 \\
\hline $\mathrm{CT}, \mathrm{cm}$ & 26.10 & 25.08 & 25.04 & 26.48 & 24.90 & 24.68 & 6.45 & 0.18 & 0.40 & 0.38 \\
\hline $\mathrm{CL}, \mathrm{cm}$ & 140.10 & 140.8 & 139.40 & 139.30 & 135.80 & 138.70 & 2.37 & 0.51 & 0.94 & 0.45 \\
\hline $\mathrm{LL}, \mathrm{cm}$ & 74.50 & 76.10 & 75.26 & 74.86 & 73.40 & 75.84 & 3.82 & 0.47 & 0.52 & 0.78 \\
\hline $\mathrm{AL}, \mathrm{cm}$ & 40.60 & 40.90 & 40.30 & 40.30 & 39.30 & 40.50 & 4.18 & 0.93 & 0.72 & 0.64 \\
\hline $\mathrm{AP}, \mathrm{cm}$ & 36.90 & 37.30 & 36.80 & 37.10 & 35.50 & 37.10 & 4.52 & 0.85 & 0.61 & 0.79 \\
\hline
\end{tabular}

$\mathrm{SW}=$ slaughter weight $\left(\hat{\mathrm{Y}}=493.372-0.691 \mathrm{BMB} ; \mathrm{P}=0.049 ; \mathrm{R}^{2}=0.20\right), \mathrm{CCW}=$ cold carcass weight $(\mathrm{Y}=493.372-0.0691 \mathrm{BMB}$; $\left.\mathrm{P}=0.049 ; \mathrm{R}^{2}=0.20\right), \mathrm{CCY}=$ cold carcass yield, $\mathrm{SFT}=$ subcutaneous fat thickness $(\mathrm{Y}, \mathrm{mm}=5.5068-0.00506 \mathrm{BMB} ; \mathrm{P}=0.019 ;$ $\left.\mathrm{R}^{2}=0.25\right)$, SFT $(\%)=2.1-0.0021 \mathrm{BMB}\left(\mathrm{P}=0.047 ; \mathrm{R}^{2}=0.24\right), \mathrm{LDA}=$ longissimus dorsi area, $\mathrm{PM}=$ physiological maturity, $\mathrm{CC}$ $=$ carcass conformation $\left(\mathrm{Y}=10.363-0.0284 \mathrm{BMB} ; \mathrm{P}=0.013 ; \mathrm{R}^{2}=0.30\right), \mathrm{CT}=$ cushion thickness, $\mathrm{CL}=\mathrm{carcass}$ length, $\mathrm{LL}=1$ eg length, $\mathrm{AL}=$ arm length, $\mathrm{AP}=$ arm perimeter, ${ }^{*} \%$ of cold carcass weight, $\mathrm{CV}=$ coefficient of variation, $\mathrm{A}=$ millet $v s$. corn diet, $\mathrm{B}$ $=$ corn $v s . \mathrm{BMB}$ diets; $\mathrm{C}=$ millet $v s . \mathrm{BMB}$ diets.

Carcass yield was unchanged $(\mathrm{P}>0.05)$ with increasing levels of BMB in the diet. In addition, no difference was observed between diets with BMB and corn- or millet-based diets, or between cornand millet-based diets (Table 3). These results can be explained by the reduction in both variables used for determining determine carcass yield, slaughter weight, and the cold carcass weight. According to Pacheco et al. (2013), slaughter weight is the main cause of the carcass yield variation, accounting for $57 \%$ of the variation of this variable. Non-carcass components, according to these same authors, are the second most important factor, accounting for $30 \%$ of the variation in carcass yield. According to Berg and Butterfield (1976), fat thickness is another important factor, as carcass yield is directly related to carcass fat tissue. In this study; however, the variation in subcutaneous fat thickness with increasing $\mathrm{BMB}$ in the diet was not sufficient to change the carcass yield. Further, the lack of carcass yield variation showed that the weight of noncarcass components was not affected by different diets. This, in a way, disagrees with the observations by Miotto et al. (2012a), who suggested that inclusion of $\mathrm{BMB}$ in the diet may contribute to the increase in the gastrointestinal tract content, due to increased food intake and decreased carcass yield. The suggestion of these authors may be due to the high BMB levels used in diets. It should be noted that the results obtained for the carcass yield were consistent with similar nutritional values and animal performance in diets with corn or millet (HILL et al., 1996; GONÇALVES et al., 2010; SILVA et al., 2014).

There was also a significant $(\mathrm{P}<0.05)$ negative relationship between $\mathrm{BMB}$ level in the diet and subcutaneous fat thickness (Table 3). There was no significant difference in this characteristic between 
BMB diets and corn- or millet-based diets, as well as between corn- and millet-based diets. The reduction in carcass fat thickness with increasing levels of BMB in the diet may be related, in part, to the reduction in the average daily weight gain caused by the reduction of the diet energy content (Table 1). According to the NRC (1996), the thickness of subcutaneous fat is directly related to weight gain rate and the composition of gained body weight. The gained weight composition, according to that same publication, is related to body weight at maturity - as body weight increases, fat content in the average daily gain weight also rises. The weight gain composition is also associated with the composition of the diet, as diets with higher content of neoglucogenic precursors increase body fat deposition. This is due to increased production of reducing potential (NAPH) via the pentose cycle, which is responsible for converting acetate in long-chain fatty acids, stored as triglycerides in adipocytes (PETHICK et al., 2004). Therefore, the reduction of subcutaneous fat thickness with increasing $\mathrm{BMB}$ inclusion level in the diet also reflects the diet composition itself, as $\mathrm{BMB}$ has a higher neutral detergent fiber content and lower non-fibrous carbohydrates content (Table 2 ), which determines lower (61.4 vs. 88.0\%) total digestible nutrients content in relation to corn (CRUZ et al., 2012). These assumptions also justify similar carcass finishing found between diets with corn or millet, as animal performance, digestion products, and diet energy content have not changed substantially by including millet in cattle diet (HILL et al., 1996; RIBEIRO et al., 2004; GONÇALVEZ et al., 2010).

The diets did not affect $(\mathrm{P}>0.05)$ physiological carcass maturity (Table 3), which was attributed to the similar period of termination, as this feature is primarily associated with age at slaughter (MÜLLER, 1987). Further, among the features that express carcass muscling (conformation, longissimus dorsi area and cushion thickness), only the conformation has been altered by experimental diets, which decreased with increasing levels of $\mathrm{BMB}$ inclusion in the diet, explained by the reduction in body weight gain rates. Despite the reduction in conformation with the increase of BMB in the diet, no difference was observed in the conformation between diets with BMB and corn- or millet-based diets, or between diets based on corn and millet. The results of this study were similar to those obtained by Miotto et al. (2012a), who found a carcass muscular reduction from the reduction of cushion thickness to the increment of BMB level in the diet, but found no differences in longissimus dorsi area and carcass conformation. The results were also consistent with those obtained by Silva et al. (2015), who found no change in conformation, longissimus dorsi area and thickness of bovine carcass fed with diets containing corn replacement levels for millet.

Carcass length, leg length, arm length and arm circumference were not changed $(\mathrm{P}>0.05)$ by the experimental diets (Table 3 ). These results are attributed to the growth profile of the bone tissue, which develops at early stages of animal growth (BERG; BUTTERFIELD, 1976). The association of metric characteristics with bone tissue, in this sense, occurs due to the skeleton being the main determinant of the length and height of the animal (LAWRENCE; FOWLER, 2002). The arm perimeter, although not directly related to the length and height of the animal, is associated with the bone tissue as it occurs in a region with little muscle and fat deposition. Considering the above, as well as the age (27 months) and the initial body weight $(371.02 \mathrm{~kg})$ of the animals, it is assumed that bone tissue development was practically complete at the beginning of the finishing period. Thereby, there was no effect of the feedlot diets on bone growth and carcass characteristics. Corroborating, Miotto et al. (2012a) and Silva et al. (2015) who found no change in the metric characteristics of carcasses fed with diets containing levels of BMB and millet, respectively.

The weight of the forequarter and the short ribs did not change $(\mathrm{P}>0.05)$ with the experimental 
diets (Table 4). In contrast, the pistol cut weight decreased linearly $(\mathrm{P}<0.05)$ as BMB levels in the diet increased. However, it did not change between diets with BMB and diets with corn or millet, or between diets with corn and millet. The variation of the results for the commercial cut may be associated with growth waves of the animal body, which occur from the ends and then into the axial skeleton and loin (LAWRENCE; FOWLER, 2002). Therefore, it is assumed that the pistol cut muscles, found in a region of delayed development relative to the front and the short ribs were most affected by the reduction in the growth rate of animals with BMB inclusion in the diet, which was reflected in the weight of this commercial cut. When expressed in relation to the carcass weight, however, there was no change in the weights of the commercial cuts in respect to the diets. These results, in a way, disagree with the results reported in the literature, demonstrating that the increase of animal body weight does not change the proportions of the forequarter, but reduces the proportion of the pistol cut to the extent that the ratio of the short ribs increases due to the increased fat deposition on the ribs with animal finishing (COSTA et al., 2002a; ARBOITTE et al., 2004). Nevertheless, the results obtained were consistent with those of Berg and Butterfield (1976), who found that the animal tends to maintain, within certain limits, a balance between the rear and front quarters. It is worth noting that the reduction of the rear is not desirable, since the compensation obtained by the slaughterhouse for a heavier pistol cut allows a better profit to the producer (VAZ et al., 2012).

Table 4. Retail cuts from steers fed diets based on pearl millet grain containing inclusion levels of babassu mesocarp bran (BMB), and standard diet based on corn grain.

\begin{tabular}{|c|c|c|c|c|c|c|c|c|c|c|}
\hline \multirow{2}{*}{ Items } & \multicolumn{5}{|c|}{$\%$ of BMB in the diet } & \multirow{2}{*}{$\begin{array}{l}\text { Corn } \\
\text { control }\end{array}$} & \multirow{2}{*}{$\begin{array}{l}\text { CV } \\
(\%)\end{array}$} & \multicolumn{3}{|c|}{ Orthogonal contrasts } \\
\hline & 0 & 12 & 24 & 36 & 48 & & & $\mathrm{~A}$ & $\mathrm{~B}$ & $\mathrm{C}$ \\
\hline $\mathrm{FQ}, \mathrm{kg}$ & 47.60 & 48.78 & 43.94 & 46.50 & 44.74 & 47.30 & 7.90 & 0.90 & 0.39 & 0.48 \\
\hline $\mathrm{FQ}, \% *$ & 39.30 & 39.42 & 38.07 & 38.78 & 39.47 & 39.57 & 2.86 & 0.62 & 0.56 & 0.23 \\
\hline $\mathrm{SR}, \mathrm{kg}$ & 14.24 & 14.68 & 13.62 & 14.14 & 14.68 & 14.46 & 10.76 & 0.82 & 0.88 & 0.96 \\
\hline $\mathrm{SR}, \%{ }^{*}$ & 11.76 & 11.86 & 11.80 & 11.79 & 12.95 & 12.10 & 3.67 & 0.13 & 0.02 & 0.64 \\
\hline $\mathrm{PC}, \mathrm{kg}$ & 59.28 & 60.28 & 57.86 & 59.28 & 53.94 & 57.76 & 7.58 & 0.59 & 0.30 & 0.52 \\
\hline $\mathrm{PC}, \%{ }^{*}$ & 48.94 & 48.72 & 50.13 & 49.43 & 47.58 & 48.33 & 2.18 & 0.89 & 0.12 & 0.16 \\
\hline
\end{tabular}

$\mathrm{FQ}=$ forequarter, $\mathrm{SR}=$ short ribs, $\mathrm{PC}=$ pistol cut $\left(\mathrm{Y}, \mathrm{kg}=60.763-0.001047 \mathrm{BMB} ; \mathrm{P}=0.014 ; \mathrm{R}^{2}=0.30\right),{ }^{*} \%$ of cold carcass weight, $\mathrm{CV}=$ coefficient of variation, $\mathrm{A}=$ millet $v s$. corn diet, $\mathrm{B}=$ corn $v s$. $\mathrm{BMB}$ diets; $\mathrm{C}=$ millet $v s$. $\mathrm{BMB}$ diets.

The experimental diets did not affect $(\mathrm{P}>0.05)$ tissue carcass composition (Table 5), demonstrating that the reduction in the performance of BMBfed animals during the finishing stage was not sufficient to alter the deposition of body tissue as a whole, nor the edible portion of the carcass. These results were similar to those obtained by Cruz et al. (2015b), who, while evaluating the addition of $35 \%$ of $\mathrm{BMB}$ in diets containing different concentrate levels (65 and 71\%) of corn, did not find any alteration in the amount of muscle, fat, and carcass bone, demonstrating the feasibility of using small amounts of this byproduct in cattle diet. Further, these results disagree with those obtained by Miotto et al. (2012b), who found a linear increase between the ratio of muscle and the increment of BMB in the diet, which was attributed to a decrease in the percentage of carcass fat starting from a BMB level of $25 \%$ in the diet. These authors also found that reducing the energy density of the diet with 
increasing $\mathrm{BMB}$ compromised body fat deposition, and therefore, the edible portion of the carcass, which was $7.7 \%$ lower in the diets with $100 \%$ $\mathrm{BMB}$ relative to diets based on corn. In contrast with the results of Miotto et al. (2012b), the results obtained in this study can be justified due to the lower levels of BMB used in diets. However, the results obtained for corn- or millet-based diets were consistent with the results obtained by Silva et al. (2015), who despite not having evaluated the tissue composition of the carcass, found that the partial or total replacement of corn by millet did not change the carcass characteristics, which is indicative of the maintenance of body tissue deposition profile.

Table 5. Tissue composition of carcasses from steers fed diets based on pearl millet grain containing inclusion levels of babassu mesocarp bran (BMB), and standard diet based on corn grain.

\begin{tabular}{|c|c|c|c|c|c|c|c|c|c|c|}
\hline \multirow{2}{*}{ Items } & \multicolumn{5}{|c|}{$\%$ of BMB in the diet } & \multirow{2}{*}{$\begin{array}{c}\text { Corn } \\
\text { control }\end{array}$} & \multirow{2}{*}{$\begin{array}{l}\mathrm{CV} \\
(\%)\end{array}$} & \multicolumn{3}{|c|}{ Orthogonal contrasts } \\
\hline & 0 & 12 & 24 & 36 & 48 & & & $\mathrm{~A}$ & $\mathrm{~B}$ & $\mathrm{C}$ \\
\hline $\mathrm{M}, \mathrm{kg}$ & 146.50 & 152.60 & 137.70 & 152.90 & 138.70 & 150.62 & 8.27 & 0.59 & 0.40 & 0.20 \\
\hline $\mathrm{M}, \%{ }^{*}$ & 60.48 & 61.66 & 59.65 & 63.75 & 61.18 & 63.01 & 3.63 & 0.14 & 0.26 & 0.44 \\
\hline $\mathrm{F}, \mathrm{kg}$ & 55.32 & 59.39 & 56.04 & 50.12 & 53.22 & 50.65 & 8.59 & 0.37 & 0.32 & 0.88 \\
\hline $\mathrm{F}, \%{ }^{*}$ & 22.84 & 24.00 & 24.28 & 20.90 & 23.47 & 21.19 & 12.51 & 0.34 & 0.17 & 0.85 \\
\hline $\mathrm{B}, \mathrm{kg}$ & 40.09 & 37.28 & 37.66 & 37.78 & 35.79 & 38.89 & 14.90 & 0.56 & 0.29 & 0.08 \\
\hline $\mathrm{B}, \%^{*}$ & 16.55 & 15.06 & 16.31 & 15.75 & 15.79 & 16.27 & 7.21 & 0.65 & 0.42 & 0.17 \\
\hline $\mathrm{M} / \mathrm{B}$ & 3.65 & 4.09 & 3.66 & 4.05 & 3.88 & 3.87 & 7.61 & 0.24 & 0.42 & 0.14 \\
\hline $\mathrm{M} / \mathrm{F}$ & 2.65 & 2.57 & 2.46 & 3.05 & 2.61 & 2.97 & 14.45 & 0.32 & 0.22 & 0.78 \\
\hline$M+F / B$ & 5.03 & 5.69 & 5.14 & 5.37 & 5.36 & 5.18 & 8.68 & 0.75 & 0.79 & 0.20 \\
\hline
\end{tabular}

$\mathrm{M}=$ muscle, $\mathrm{F}=$ fat, $\mathrm{B}=$ bone,${ }^{*} \%$ of cold carcass weight, $\mathrm{CV}=$ coefficient of variation, $\mathrm{A}=$ millet $v s$. corn diet, $\mathrm{B}=$ corn $v s . \mathrm{BMB}$ diets; $\mathrm{C}=$ millet $v s$. BMB diets.

The marbling of the meat was not influenced $(\mathrm{P}>0.05)$ by the BMB level included in the diet, and did not differ among diets with BMB and diets with corn or millet, or between diets based on corn and millet (Table 6). These results were similar to those obtained by Miotto et al. (2012b) and Cruz et al. (2015b), who found that the amount of intramuscular fat in the meat was not influenced by the BMB level in the feedlot diet. Regarding diets based on corn or millet, the results of the present study were consistent with those obtained by Silva et al. (2014), who found no change in the marbling of feedlot beef cattle with diets containing $0,33,66$, and $100 \%$ replacement of corn with millet, a fact attributed to the similar energy concentration between these diets. It is worth noting that marbling of the meat can be crucial to consumer market due to the improved palatability of the meat (PEROBELLI et al., 1994; RESTLE et al., 1996). This association between marbling and palatability, according to Costa et al. (2002b), is associated with the presence of fat contained in flavoring substances within muscle cells. Moreover, increased marbling is important for improving the meat quality as it reduces fluid loss during cooking, shortens muscle fibers by cold, and increases the solubility of collagen and the softness of the meat (LI et al., 2006). 
Table 6. Marbling, texture and color of meat from steers fed diets based on pearl millet grain containing inclusion levels of babassu mesocarp bran (BMB), and standard diet based on corn grain.

\begin{tabular}{|c|c|c|c|c|c|c|c|c|c|c|}
\hline \multirow{2}{*}{ Items } & \multicolumn{5}{|c|}{$\%$ of BMB in the diet } & \multirow{2}{*}{$\begin{array}{l}\text { Corn } \\
\text { control }\end{array}$} & \multirow{2}{*}{$\begin{array}{l}\mathrm{CV} \\
(\%)\end{array}$} & \multicolumn{3}{|c|}{ Orthogonal contrasts } \\
\hline & 0 & 12 & 24 & 36 & 48 & & & A & B & $\mathrm{C}$ \\
\hline Marbling, points & 5.00 & 7.40 & 6.60 & 4.20 & 4.40 & 6.20 & 22.57 & 0.48 & 0.68 & 0.63 \\
\hline Texture, points & 3.80 & 3.98 & 2.74 & 3.22 & 3.02 & 3.74 & 22.52 & 0.90 & 0.21 & 0.16 \\
\hline Color, points & 3.14 & 2.92 & 3.22 & 3.32 & 2.66 & 3.06 & 16.83 & 0.81 & 0.91 & 0.41 \\
\hline
\end{tabular}

$\mathrm{CV}=$ coefficient of variation, $\mathrm{A}=$ millet $v s$. corn diet, $\mathrm{B}=$ corn $v s$. $\mathrm{BMB}$ diets; $\mathrm{C}=$ millet $v s . \mathrm{BMB}$ diets.

The texture of the meat did not change $(\mathrm{P}>$ 0.05 ) when fed on the experimental diets (Table 6), which can be attributed to a similar finishing period to which the animals were subjected. According to Müller (1987), meat texture is primarily associated with the age of the animals; young cattle have a finer texture meat than older animals. The results were similar to those obtained by Miotto et al. (2012b) and Cruz et al. (2015b), who found that the texture of the meat was not influenced by the BMB level in the cattle diet. Similarly, with regard to the millet or corn diets, the results of this study were consistent with those obtained by Silva et al. (2014), who found no change in cattle meat texture fed with diets with partial or total replacement of corn by millet, which was attributed to a similar slaughter age.

The BMB inclusion level did not affect $(\mathrm{P}>$ $0.05)$ the color of meat, nor were there differences in this trait among diets with BMB and diets with corn or millet, or between diets based on corn and millet (Table 6). These results can be attributed to similar slaughter age of the animals, which was the result of a similar period of finishing. This feature is primarily associated with the age of the animals, since the amount of circulating myoglobin increases with advancing age (OURY et al., 2009) and rarely varies with diet (AHEMED et al., 2006). It is worth noting that the results obtained were in agreement with those presented in the literature (MIOTTO et al., 2012b; SILVA et al., 2014; CRUZ et al., 2015b), where it has been shown that the color of the meat was not influenced by total or partial replacement of the corn by BMB or millet in feedlot cattle diet.

\section{Conclusions}

The inclusion of BMB in millet-based diets should consider the cost/benefit ratio, as it promotes a drop in slaughter and carcass weight, while having no effect on the main meat characteristics. In addition, total substitution of corn by millet grains in feedlot diets does not alter the main features of bovine carcass and meat.

\section{References}

AHEMED, S. S.; JOSEF, K.; HANS, E.; PETER, F.; FRIEDER, J. S. Effects of the dietary energy source on meat quality and eating quality attributes and fatty acid profile of Simmental bulls. Animal Research, Les Ulis, v. 55, n. 4, p. 287-299, 2006.

ARBOITTE, M. Z.; RESTLE, J.; ALVES FILHO, D. C.; PASCOAL, L. L.; PACHECO, P. S.; SOCCAL, D. C. Características da carcaça de novilhos $5 / 8$ Nelore - 3/8 Charolês abatidos em diferentes estádios de desenvolvimento. Revista Brasileira de Zootecnia, Viçosa, MG, v. 33, n. 4, p. 969-977, 2004.

ASSOCIATION OF OFFICIAL ANALYTICAL CHEMISTS - AOAC. Official methods of analysis. $16^{\text {th }}$ ed. Arlington: AOAC International, 1995. $1025 \mathrm{p}$.

BERG, R. T.; BUTTERFIELD, R. M. New concepts of cattle growth. New York: Sydney University, 1976. 240 p.

BERGAMASCHINE, A. F.; FREITAS, R. V. L.; VALÉRIO FILHO, W. V.; BASTOS, J. F. P.; MELLO, S. Q. S. AND CAMPOS, Z. R. Substituição do milho e farelo de algodão pelo milheto no concentrado da dieta de novilhos em confinamento. Revista Brasileira de Zootecnia, Viçosa, MG, v. 40, n. 1, p. 154-159, 2011. 
COSTA, E. C.; RESTLE, J.; BRONDANI, I. L.; PEROTTONI, J.; FATURI, C.; MENEZES, L. F. G. Composição física da carcaça, qualidade da carne e conteúdo de colesterol no músculo longissimus dorsi de novilhos Red Angus superprecoce. Revista Brasileira de Zootecnia, Viçosa, MG, v. 31, n. 1, p. 417-428, 2002b. Suplemento.

COSTA, E. C.; RESTLE, J.; VAS, F. N.; ALVES FILHO, D. C.; BERNARDES, R. A. L. C.; KUSS, F. Características da carcaça de novilhos Red Angus superprecoces abatidos com diferentes pesos. Revista Brasileira de Zootecnia, Viçosa, MG, v. 31, p. 417-428, 2002a. Suplemento.

CRUZ, R. S.; ALEXANDRINO, E.; MISSIO, R. L.; NEIVA, J. N. M.; RESLTE, J.; MELO, J. C.; SOUSA JÚNIOR, A.; RESENDE, J. M. Feeding behaviors of feedlot bulls fed concentrate levels and babassu mesocarp meal. Revista Brasileira de Zootecnia, Viçosa, MG, v. 41, n. 7, p. 1727-1736, 2012.

CRUZ, R. S.; ALEXANDRINO, E.; MISSIO, R. L.; NEIVA, J. N. M.; RESTLE, J.; MELO, J. C.; PAULA NETO, J. J.; SILVA, D. P.; DUARTE, T. D.; SILVA, A. A. M. Características das carcaças e carne de tourinhos Nelore alimentados com níveis de concentrado e farelo do mesocarpo de babaçu. Arquivo Brasileiro de Medicina Veterinária e Zootecnia, Belo Horizonte, v. 67, n. 1, p. 299-308, 2015 b.

CRUZ, R. S.; ALEXANDRINO, E.; MISSIO, R. L.; RESTlE, J.; MELO, J. C.; PAULA NETO, J. J. P.; SILVA, A. A. M.; SILVA, D. P. Níveis de concentrado e farelo do mesocarpo de babaçu sobre as características da carcaça de tourinhos confinados. Bioscience Journal, Uberaba, v. 31, n. 1, p. 73-86, 2015a.

CRUZ, R. S.; ALEXANDRINO, E.; MISSIO, R. L.; RESTLE, J.; MELO, J. C.; PAULA NETO, J.; NEIVA, J. N. M.; MENDES FILHO, G. O.; SOUZA JÚNIOR, A.; DUARTE, T. T.; REZENDE, J. M.; SILVA, A. A. M. Desempenho bioeconômico de tourinhos alimentados com níveis de concentrado e farelo do mesocarpo de babaçu. Semina: Ciências Agrárias, Londrina, v. 35, n. 4, p. 2159-2174, 2014.

GONÇALVES, J. R. S.; PIRES, A. V.; SUSIN, I.; LIMA, L. G.; MENDES, C. Q.; FERREIRA, E. M. Substituição milho pelo milheto em dietas contendo silagem milho ou silagem de capim-elefante na alimentação de bovinos de corte. Revista Brasileira de Zootecnia, Viçosa, MG, v. 39, n. 9, p. 2032-2039, 2010.

HANKINS, O. G.; HOWE, P. E. Estimation of composition of beef carcasses and cuts. Washington, D.C.: USDA, 1946. 20 p. (Tecnical Bulletin USDA, 926).
HILL, G. M.; NEWTON, G. L.; STREETER, M. N.; HANNA, W. W.; UTLEY, P. R.; MATHIS, M. J. Digestibility and utilization of pearl millet diets fed to finishing beef cattle. Journal of Animal Science, Champaign, v. 74, n. 7, p. 1728-1735, 1996.

KUSS, F.; LÓPEZ, J.; RESTLE, J.; BARCELLOS, J. O. J.; MOLETTA, J. L.; LEITE, M. C. P. Qualidade da carne de novilhos terminados em confinamento e abatidos aos 16 ou 26 meses de idade. Revista Brasileira de Zootecnia, Viçosa, MG, v. 39, n. 4, p. 924-931, 2010.

LAWRENCE, T.; FOWLER, V. Growth of farm animals. London: CAB International. 2002. $330 \mathrm{p}$.

LI, C.; ZHOU, G.; XU, X.; ZHANG, J.; XU, S.; JI, Y. Effects of marbling on meat quality characteristics and intramuscular connective tissue of beef Longissimus muscle. Asian-Australian Journal Animal Science, Seoul, v. 19, n. 12, p. 1719-1808, 2006.

MENEZES, L. F. G.; RESTLE, J.; BRONDANI, I. L.; SILVEIRA, M. F.; FREITAS, L. S.; PIZZUTI, L. A. D. Características da carcaça e da carne de novilhos superjovens da raça Devon terminados em diferentes sistemas de alimentação. Revista Brasileira de Zootecnia, Viçosa, MG, v. 39, n. 3, p. 667-676, 2010.

MIOTTO, F. R. C.; RESTlE, J.; NEIVA, J. N. M.; LAGE, M. E.; CASTRO, K. J.; ALEXANDRINO, E. Farelo do mesocarpo do babaçu na terminação de tourinhos: características da carcaça e cortes secundários do traseiro especial. Ciência Animal, Santa Maria, v. 13, n. 4, p. 440-449, 2012a.

MIOTTO, F. R. C.; RESTLE, J.; NEIVA, J. N. M.; RESENDE, P. L. P.; LAGE, M. E.; PRADO, C. S.; PADUA, J. T.; ARAÚJO, V. L. Farelo de mesocarpo de babaçu (Orbygnia sp.) na terminação de bovinos: composição física da carcaça e qualidade da carne. Ciência Rural, Santa Maria, v. 42, n. 7, p. 1271-1277, 2012b.

MISSIO, R. L.; BRONDANIM, I. L.; ALVES FILHO, D. C.; RESTLE, J.; ARBOITTE, M. Z.; SEGABINAZZI, L. R. Características da carcaça e da carne de tourinhos terminados em confinamento, recebendo diferentes níveis de concentrado na dieta. Revista Brasileira de Zootecnia, Viçosa, MG, v. 39, n. 7, p. 1610-1617, 2010.

MÜLLER, L. Normas para avaliação de carcaças e concurso de carcaças de novilhos. 2. ed. Santa Maria: Universidade Federal de Santa Maria, 1987. 31 p.

NATIONAL RESEARCH COUNCIL - NRC. Nutrients requirements of beef cattle. $7^{\text {th }}$ ed. Washington, D.C., 1996. $242 \mathrm{p}$. 
OURY, M.; PIERRET, P.; COULMIER, D.; DUMONT, R. Eléménts de maîtrise de la couleur des viandes chez les bovins de race Charolaise. INRA Productions Animales, Clermont Ferrand, v. 22, n. 2, p. 131-140, 2009.

PACHECO, P. S.; RESTLE, J.; MISSIO, R. L.; MENEZES, L. F. G.; ROSA, J. R. P.; KUSS, F.; ALVES FILHO, D. C.; NEIVA, J. N. M.; DONICH, P. A. M. M. Características da carcaça e do corpo vazio de bovinos Charolês de diferentes categorias abatidos com similar grau de acabamento. Arquivo Brasileiro de Medicina Veterinária e Zootecnia, Belo Horizonte, v. 65, n. 1, p. 281-288, 2013.

PEROBELLI, Z. V.; MULLER, L.; RESTLE, J. Estudo da qualidade das carcaças e da carne de vacas de descarte de dois grupos genéticos. Ciência Rural, Santa Maria, v. 24, n. 3, p. 613-616, 1994.

PETHICK, D. W.; HARPER, G. S.; ODDY, V. H. Growth, development and nutritional manipulation of marbling in cattle: a review. Australian Journal of Experimental Agriculture, Collingwood, v. 44, n. 7, p. 705-715, 2004.

RESTLE, J.; KEPLIN, L. A. S.; VAZ, F. N.; MULLER, L. Qualidade da carne de novilhos Charolês confinados e abatidos com diferentes pesos. Ciência Rural, Santa Maria, v. 26, n. 3, p. 463-466, 1996.

RESTLE, J.; PACHECO, P. S.; COSTA, E. C.; FREITAS, A. K.; VAZ, F. N.; BRONDANI, I. L.; FERNANDES, J. J. R. Apreciação econômica da terminação em confinamento de novilhos red angus superjovens abatidos com diferentes pesos. Revista Brasileira de Zootecnia, Viçosa, MG, v. 36, n. 4, p. 978-986, 2007.

RIBEIRO, C. V. D. M.; PIRES, A. V.; SIMAS, J. M. C.; SANTOS, F. A. P.; SUSIN, I.; OLIVEIRA JUNIOR, R. C. Substituição milho pelo Milheto (Pennisetum americanum) na dieta de vacas Holandesas em lactação. Revista Brasileira de Zootecnia, Viçosa, MG, v. 33, n. 5, p. 1351-1359, 2004.

SILVA, A. H. G.; RESTLE, J.; MISSIO, R. L.; BILEGO, U. O.; FERNANDES, J. J. R.; REZENDE, P. L. P.; SILVA, R. M.; PEREIRA, M. L. R.; LINO, F. A. Milheto em substituição ao milho na dieta de novilhos confinados. Semina: Ciências Agrárias, Londrina, v. 35, n. 4, p. 2077-2094, 2014.
SILVA, N. R. da; FERREIRA, A. C. H.; FATURI, C.; SILVA, G. F. da; MISSIO, R. L.; NEIVA, J. N. M.; ARAÚJO, V. L.; ALEXANDRINO, E. Desempenho em confinamento de bovinos de corte, castrados ou não, alimentados com teores crescentes de farelo do mesocarpo de babaçu. Ciência Rural, Santa Maria, v. 42, n. 10 , p. 1882-1887, 2012.

SILVA, R. M.; RESTLE, J.; MISSIO, R. L.; BILEGO, U. O.; PACHECO, P. S.; RESENDE, P. L. P.; FERNANDES, J. J. R.; SILVA, A. H. G.; PÁDUA, J. T. Características de carcaça e carne de novilhos de diferentes predominâncias genéticas alimentados com dietas contendo níveis de substituição do grão de milho pelo grão de milheto. Semina: Ciência Agrárias, Londrina, v. 36, n. 2, p. 943$960,2015$.

SNIFFEN, C. J.; O'CONNOR, J. D.; VAN SOEST, P. J.; FOX, D. G.; RUSSEL, J. B. A net carbohydrate and protein system for evaluating cattle diets: II. Carbohydrate and protein availability. Journal of Animal Science, Champaign, v. 70, n. 12, p. 3562-3577, 1992.

TEIXEIRA, M. A. Babassu - a new approach for an ancient Brazilian biomass. Biomass and Bioenergy, New York, v. 32, n. 9, p. 857-864, 2008.

TEIXEIRA, M. A.; CARVALHO, M. da. G. Regulatory mechanism for biomass renewable energy in Brazil, a case study of the Brazilian Babassu oil extraction industry. Energy, New York, v. 32, n. 6, p. 999-1005, 2007.

VAN SOEST, P. J.; ROBERTSON, J. B.; LEWIS, B. A. Methods for dietary fiber, neutral detergent fiber, and nonstarch polyssacarides in relation to animal nutrition. Journal of Animal Science, Champaign, v. 74, n. 10, p. 3583-3597, 1991.

VAZ, F. N.; VAZ, R. Z.; PASCOAL, L. L.; PACHECO, P. S.; MIOTTO, F. R. C.; TEIXEIRA, N. P. Análise econômica, rendimentos de carcaça e dos cortes comerciais de vacas de descarte 5/8 Hereford 3/8 Nelore abatidas em diferentes graus de acabamento. Ciência Animal Brasileira, Goiânia, v. 13, n. 3, p. 338-345, 2012. 